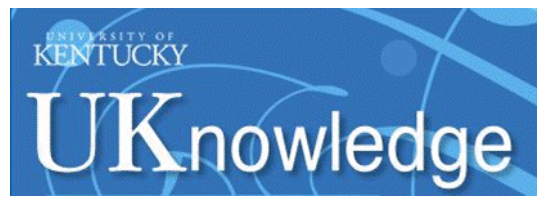

University of Kentucky

UKnowledge

\title{
An Exploration of Sexual Victimization and Academic Performance Among College Women
}

\author{
Carol E. Jordan \\ University of Kentucky, carol.j@uky.edu \\ Jessica L. Combs \\ University of Kentucky, jessica.combs3@uky.edu \\ Gregory T. Smith \\ University of Kentucky, gsmith@uky.edu
}

Follow this and additional works at: https://uknowledge.uky.edu/ipsvaw_facpub

Part of the Criminology Commons, and the Law and Gender Commons

Right click to open a feedback form in a new tab to let us know how this document benefits you.

\section{Repository Citation}

Jordan, Carol E.; Combs, Jessica L.; and Smith, Gregory T., "An Exploration of Sexual Victimization and Academic Performance Among College Women" (2014). Office for Policy Studies on Violence Against Women Publications. 38.

https://uknowledge.uky.edu/ipsvaw_facpub/38

This Article is brought to you for free and open access by the Policy Studies on Violence Against Women at UKnowledge. It has been accepted for inclusion in Office for Policy Studies on Violence Against Women Publications by an authorized administrator of UKnowledge. For more information, please contact UKnowledge@lsv.uky.edu. 


\section{An Exploration of Sexual Victimization and Academic Performance Among College Women}

Digital Object Identifier (DOI)

http://dx.doi.org/10.1177/1524838014520637

Notes/Citation Information

Published in Trauma Violence Abuse, v. 15, no. 3, p. 191-200.

The document available for download is the authors' post-peer-review final draft of the article. 
Running Head: VICTIMIZATION AND ACADEMIC PERFORMANCE AMONG COLLEGE WOMEN

Jordan, C.E., Combs, J.L., \& Smith, G.T. (2014). An exploration of victimization and academic performance among college women. Trauma, Violence \& Abuse: A Review Journal.

An Exploration of Sexual Victimization and Academic Performance among College Women

\author{
Carol E. Jordan ${ }^{1}$ \\ Jessica L. Combs ${ }^{2}$ \\ Gregory T. Smith ${ }^{3}$
}

\footnotetext{
${ }^{1}$ Corresponding Author: Carol E. Jordan, Executive Director, Offic for Violence Against Women Policy Studies University of Kentucky, Lexington, Kentucky 40506-0059

Phone: 859-227-7495, Email: carol.jordan@uky.edu

${ }^{2}$ Department of Psychology, University of Kentucky

${ }^{3}$ Department of Psychology, University of Kentucky
} 
Running Head: VICTIMIZATION AND ACADEMIC PERFORMANCE AMONG COLLEGE WOMEN

An Exploration of Sexual Victimization and Academic Performance among College Women 


\begin{abstract}
The literature has documented the widespread nature of sexual assault victimization among college women. While the aftermath of violence against university women has also received focus, documenting trauma-related sequelae, risk factors, reporting patterns, and legal interventions; the impact on academic performance has not received adequate attention in the literature. The primary purpose of this study was to explore the association of rape and sexual assault with academic performance among college women. Its specific aims included: to compare high school and college sexual assault experiences with collegiate grade point averages (GPA) at key points in time; to examine any differences in GPA by type of sexual assault; to urge researchers studying retention and persistence patterns or sexual assault among college students to ensure that the relationship between the two is included in research designs; and to recommend that academic institutions expand programming on retention to include rape and sexual assault among the risk factors associated with a lack of persistence.
\end{abstract}

Key Words: victimization, sexual assault, academic performance, retention, women 
Introduction

Studies make clear that women who attend academic institutions in states across the country are at substantial risk of experiencing sexual assault, and in fact are at greater risk for certain forms of assault than are women in the general population or in a comparable age group (Belknap \& Erez, 1995; Fisher, Cullen, \& Turner, 2000; Koss, Gidycz, \& Wisniewski, 1987). Across many studies, a consistent one in four to one in three college women report experiencing an act that meets the legal definition of rape or attempted rape (e.g., Abbey, Parkhill, BeShears, ClintonSherrod, \& Zawacki, 2006; Humphrey \& White, 2000; Koss, Gidycz, \& Wisniewski, 1987; White \& Koss, 1991; Wilcox, Jordan, \& Pritchard, 2006). Bonnie Fisher and her colleagues have estimated that a college with 10,000 female students would see more than 350 rapes each year (Fisher et al., 2000). With respect to completed rapes, scholars have noted that the 15 percent prevalence estimate has not changed over the twenty years during which research has reported findings on the sexual victimization of college women (Rozee \& Koss, 2001).

Research also makes clear that the crime covers the broad spectrum of races. Rates of sexual assault experienced by Black, Hispanic, Asian and White college women appear to be relatively comparable (Abbey, Ross, McDuffie, \& McAuslan, 1996; Mills \& Granoff, 1992; Smith, White \& Holland, 2003).

Studies on prevalence have not been limited to victimization surveys, but have also used self-report offending data to reveal a comparably sized problem. Studies of college men have found that 25 to 57 percent (a range influenced by the measure used in the studies) of men acknowledge committing some form of sexual assault, up to 15 percent of whom reported having committed an act meeting the legal definition of forcible rape (Abbey, McAuslan, \& Ross, 1998; 
Abbey, McAuslan, Zawacki, Clinton, \& Buck, 2001; Koss, Gidycz, \& Wisniewski, 1987;

Muehlenhard \& Linton, 1987). In a more recent study, 20\% of college men admitted to committing sexual dating violence (Schwartz, DeKeseredy, Tait, \& Alvi, 2001); and in another, approximately two-thirds of college men who acknowledge having committed sexual assault report committing multiple acts (Abbey, McAuslan, \& Ross, 1998).

Exposure to victimization is not limited to female college students, but also touches adolescent girls (Danielson \& Holmes, 2004); in fact the highest estimates of sexual assault are found in this younger population of women. Studies find, for example, that women aged sixteen to nineteen are four times more likely than the general population to report sexual assault, rape, and attempted rape (Rennison, 2001). A recent study among pre-college girls in grades seven through twelve found 51 percent reporting some form of sexual abuse (Young, Grey, \& Boyd, 2009). Of those adolescents who reported sexual abuse, a full 12 percent reported rape, six percent reported forced oral sex, and one percent reported attempted rape. In 1998, the National Violence Against Women Survey noted that one out of every six women has been the victim of rape or attempted rape by the age of 18 (Tjaden \& Thoennes, 1998, 2006). Almost one-third (32\%) of these assaults took place between the ages of 12 and 17 years. Similarly, in the National Survey of Adolescents funded by the National Institute of Justice, eight percent of teens surveyed reported that they had been sexually assaulted (Kilpatrick, Saunders, \& Smith, 2003). In the National Survey of Children's Exposure to Violence, 14 percent of girls aged 14 to 17 had been victims of completed or attempted rape in their lifetimes, and six percent reported that the violence had occurred in the past year (Finkelhor, Turner, Ormrod, \& Hamby, 2009). Maxwell, Robinson, and Post (2003) found that, on average, nine percent of adolescents have been sexually assaulted. Finally, in a nationally representative sample of schools, 12 percent of girls 
in $9^{\text {th }}$ through $12^{\text {th }}$ grades reported they had experienced some form of sexual abuse (Schoen, Davis, Collins, Greenberg, Des Roches, \& Abrams, 1997).

\section{The Impact of Rape on Female College Students}

Beyond identifying the prevalence of sexual assault on college campuses, the literature has also focused on the impact these crimes have on victims. For decades, research has documented the robust impact on women's mental health of intimate partner violence, stalking, rape, and psychological aggression; and in fact, most forms of major nonorganic mental distress and disorder have been associated with these forms of intimate victimization (Briere \& Jordan, 2004). In the area of rape, research has identified shock, confusion, fear, agitation, and social withdrawal in the immediate aftermath of sexual violence (e.g., Herman, 1992); and posttraumatic stress disorder, depression, acute fear and anxiety, generalized anxiety, and suicidality among the long-term effects (Campbell, et al., 2009; Jordan, Campbell, \& Follingstad, 2010). Research has gone so far as to suggest that the impact of rape may be more severe than other crimes. For example, a study by Faravelli and colleagues (2004) compared rape survivors to victims of non-sexual crimes (e.g., assault or robbery) and found higher levels of depression, eating disorders, and anxiety disorders among women having experienced a rape. For college women, documented effects are similar. The psychological and somatic sequelae of rape has been found to include negatively altered self-schemas, disordered eating, chronic pain, anxiety, depression, and posttraumatic stress disorder as well as impairment in social, work, and family domains (e.g., Amar \& Gennaro, 2005; Kaura \& Lohman, 2007; Koss, et al., 1994). Adolescent victims have been documented to experience the same type of sequelae following rape and sexual assault, specifically including feelings of guilt and shame; depression; anxiety; and posttraumatic stress disorder (Ackard \& Neumark- Sztainer, 2002); sleep disturbances, eating 
disorders, drug and alcohol use, and suicidality (Raj, Silverman, Amaro, 2000; Silverman, Raj, Mucci, \& Hathaway, 2001).

In addition to psychological sequelae, the literature has explored the association between sexual assault and alcohol use. Historically, the literature has reported that at least 50 percent of sexual assaults involving college students are associated with alcohol use (Abbey, 2002; Abbey, McAuslan, \& Ross, 1998; Abbey, Ross, McDuffie, \& McAuslan, 1996; Abbey, Zawacki, Buck, Clinton, \& McAuslan, 2001; Copenhaver \& Grauerholz, 1991; Harrington \& Leitenberg, 1994). In one study, nearly three-fourths (72\%) of the women who reported being raped during their college years were raped while they were under the influence of alcohol (Mohler-Kuo, Dowdall, Koss, \& Wechsler, 2004). Additionally, college women who report a history of sexual assault prior to college are more likely to drink alcohol, binge drink alcohol, and have negative consequences from their drinking (Combs, Jordan, \& Smith, in press; Ross, Kolars, Krahn, Gomberg, Clark, \& Niehaus, 2011). Alcohol-involved sexual assaults appear to be more common among White college students than among Black college students (Abbey et al., 1996; Harrington and Leitenberg, 1994), but rates of alcohol-related sexual assault have not been examined in other ethnic groups (Abbey, 2002).

While all college women are at risk of violence-exposure, evidence suggests that for some women, the risk is more acute. Alcohol, for example, increases the likelihood of sexual assault occurring through several interrelated pathways. As noted by Abbey, "these pathways include beliefs about alcohol, deficits in higher order cognitive processing and motor impairments induced by alcohol and peer group norms that encourage heavy drinking and forced sex” (Abbey, 2002, page 125). Of particular relevance to this study, past victimization has also been identified as a risk factor for sexual assault. Among the main factors that consistently 
increased the risk of sexual victimization among college women in their study, Fisher and Cullen found that having been a victim of a sexual assault before the start of the current school year was associated with higher risk (Fisher, Cullen, \& Turner, 2000). Some contend that the revictimization risk is high for women who, in contrast to men, appear to adapt to early victimization by internalizing the trauma which leads to depression, decreased self-esteem, and substance use. These adverse consequences of victimization may influence choices related to interpersonal relationships and acceptance of abusive behaviors (Rhea, Chafey, Dohner, \& Terragno, 1996).

The literature on victimization, mental health impacts, risk, and revictimization would suggest that these phenomena are linked for college women. This conceptualization, while now well established, leaves out a major domain in the lives of female students, however, and that is the association of victimization and academic performance. Several related studies would suggest that this is a major omission. Smith, White, and Holland (2003), for example, conducted a longitudinal study over four years' time of college women having experienced physical assault by a partner. They found that women who reported more psychological distress were more likely to drop out of college. Also relating to physical assault, victims of intimate partner or dating violence in one study reported that they had felt abandoned by the institution they attended because they perceived that their reports of abuse were not believed (Amar \& Gennaro, 2005). Study authors surmised that the victims’ reports of violence and associated changes in routines and behaviors may lead to decreased class attendance and, ultimately, to college failure (Amar \& Gennaro, 2005). Similarly, women who reported being sexually harassed by persons in positions of power at their universities also reported decreased school attendance, decreased quality and quantity of work, and dropping grades (van Roosmalen \& McDaniel, 1998). As noted by Fisher 
and Sloan (2007), sexual harassment has also been explored, including in a recent study in which researchers identified relationships between experiences of sexual harassment and psychological distress; academic disengagement; and academic performance (Huerta, Cortina, Pang, Torges, \& Magley, 2006). More recently, the victimization literature has also examined factors associated with traumatic experiences of violence and abuse on college success. Those studies have primarily looked at childhood maltreatment (e.g., Duncan 2000); alcohol (e.g., Thombs, Olds, Bondy, Winchell, Baliunas, \& Rehm, 2009); and bullying and peer victimization (e.g., Hammig \& Jozkowski, 2013). These studies give modest acknowledgement that victimization may impact a victim's academic career, but a robust exploration of this relationship is still needed.

\section{College Success: Retention and Persistence Research}

For the past several decades, multiple disciplines have conducted studies on the drop out behavior of college students. Studies focusing on retention, often defined as the percentage of full-time students who complete a degree program at a four-year university in six years' time, have compared public and private institutions, finding that for students who began their collegiate career in a public or private four-year institution, 58 percent earned their bachelor's degree (Berkner, He, Cataldi, Knepper, 2002; National Center for Education Statistics, 2003). The likelihood of earning a college degree (both two- and four-year) has been found to vary, not only across types of institutions, but also based on individual characteristics of students (Tinto, 2004). Data show, for example, that students from high income backgrounds (dependent family incomes of $\$ 70,000$ or greater), 65 percent earned some type of college degree within six years, while only about 50 percent of low-income students (dependent family incomes of less than $\$ 25,000$ ) earn some type of college degree within six years (NCES, 2003) 
The association of gender, race, and ethnicity has also been explored, finding that among males and females, the graduation rate within six years was $54.2 \%$ and $60 \%$, respectively. The graduation rate among White, Black, Hispanic, and Asian/Pacific Island students were 60.3\%, 41.5\%, 48.3\%, and 66.5\% respectively (NCES, 2009).

A number of psychological, sociological, and economic theories have been developed to explain student retention and drop out risk (Braxton, Hirschy, \& McClendon, 2004; Harper \& Quaye, 2009). In one of the early theoretical models, Vincent Tinto (1993) theorized that individual students possess specific pre-college characteristics which contribute to their likelihood of remaining at their universities through graduation. These characteristics include socioeconomic status and background, personal attributes and educational experiences prior to entering college. Pre-college characteristics have been found to strongly influence a student's initial commitment to a higher education career, which affects their capacity to persist (Braxton, 2000). Tinto has also offered a Student Integration Model (1975) which illustrates a process by which students integrate academically and socially into their college environments. Academic integration relates to a student's grade performance and intellectual development, while social integration results from a student's transactions with faculty and peers (Grayson \& Grayson, 2003). On the social integration side, empirical research suggests that student engagement is a key influence on a student's degree completion, and in fact some have suggested that student engagement is the single most significant factor impacting rates of retention (Harper \& Quaye, 2009). Success in academics and engagement is surmised to heavily influence the likelihood of finishing a college career.

Research has also identified individual characteristics and experiences that may place a student at risk for dropping out (Tinto, 2007). Risk factors examined in the extant literature 
include status as a historically underserved student, specifically including racial and ethnic minorities and first generation college students (Berkner et al., 2002; Carey, 2004; NCES, 2009); part-time enrollment, delaying entry into postsecondary education after high school, and poor academic performance (e.g., NCES, 2003); alcohol use and abuse (e.g., Thombs, et al., 2009); financial barriers (Gupton, Castelo-Rodriguez, Martinez, \& Quintanar, 2009). Other risk factors include not having a regular high school diploma, having children, being a single parent, being financially independent of parents, and working full time while enrolled (NCES, 2003).

Beyond exploring drop-out rates and risk factors, the retention literature has begun to provide recommendations to universities on how to reduce the early departure of their students. Most often the suggestions address providing financial support; emphasizing academic support; and providing faculty, staff, and peer advising, counseling, and mentoring (Tinto, 2004).

While the retention literature has exposed factors associated with dropping out, glaring in its absence is any discussion of the sexual assault of female students as a risk factor for dropping out. Perhaps invisibly covered under the “culture” of a university, or a student’s ability to engage, the specific experience of rape is inadequately covered in retention studies. One possible reason why experiencing traumatic events has not been included in the literature on attrition is due to the insight required of a student to know that the assault led to depression which then led to decreased class attendance and lower grades. A second factor may be that, in universities, those who focus on the academic side of the educational experience are perhaps unlikely or ill-prepared to ask questions about rape experiences, leaving those inquiries to police or disciplinary officials on campuses.

The victimization literature has identified physical and mental health sequelae often present in the aftermath of sexual assault, but has not addressed whether the academic domain of 
a college woman's life is also affected. Similarly, scholarship on retention and persistence patterns among college students suggests that certain individual factors and experiences impact the rate at which students drop out of college, but studies have not measured whether rape and sexual abuse experiences are among those influential factors. The intent of this paper is to address both of these scholarly gaps by examining the relationship between sexual assault victimization and academic performance among college women.

\section{Method}

\section{Participants}

Participants for this study were part of a larger study called the Trauma, Personality, and Behavior Study, which was designed to assess the development of several different types of dysfunctional behaviors following any form of sexual assault during the adolescent to college years. The initial sample consisted of women who were incoming freshmen to the University of Kentucky and who began participation in the study during the summer before they began college. A sample of 750 women participated at three different time points: summer before freshman year (T1), end of first semester freshman year (T2) and end of second semester freshman year (T3). In July, all incoming freshman women $(1,800)$ received an e-mail with a request and instructions for completing the web-based study. Of the 1,800 approached via email, 750 or $42 \%$ agreed to participate. The retention rate was $75 \%$ from Time 1 to Time 2 and $76 \%$ from Time 1 to Time 3. Retained and lost participants did not differ on any study variables. All participants were at least 18-years-old. Almost 90\% of participants identified as Caucasian, 7.7\% identified as African-American, 2.8\% identified as Asian, 0.4\% identified as Native American, and $0.3 \%$ identified as Pacific Islander. When asked about estimated household income, 39.5\% 
reported their household income as over $\$ 80,000$ per year, $24.7 \%$ reported a household income of $\$ 40,000$ to $\$ 80,000$ per year, $15.2 \%$ reported an income of $\$ 10,000$ to $\$ 40,000$, 3.5\% reported less than $\$ 10,000$ per year, and $17.0 \%$ reported that they did not know.

\section{Procedure}

The study was available online and was administered in the summer of 2011 prior to the participants' first day of move-in to the University. Eligibility was determined by questions regarding age (only students 18-years-old and older were included so as to ensure active consent), gender (only women), nature of enrollment (only what was termed traditional enrollment, defined as within three years of completing high school), and English-speaking ability. After indicating active consent, each participant was given access to the questionnaire, which took one to two hours to complete. Upon completion of T1, participants were entered in a raffle to win one of eight $\$ 250$ gift cards to a local store. For T2 and T3, each participant that participated in T1 was emailed and asked to continue participating in the study for a compensation of \$10 per wave. The University of Kentucky Institutional Review Board approved this procedure.

\section{Measures}

Demographic Information. The participants filled out a demographic questionnaire obtaining information on estimated household income, age, ethnicity, parents' education, sexual orientation and GPA (see below).

GPA. Grade point average (or GPA) was assessed at each time point using the following questions: for high school GPA (assessed at T1), participants were asked to choose their academic performance in high school from four choices (high school GPA of 3.5 or above, high school GPA of 2.5 to 3.4, high school GPA of 2.0 to 2.5, and high school GPA of below 2.0). 
The same question was asked at T2 and T3, edited to reflect current college GPA as opposed to high school GPA.

Sexual Experiences Survey (SES; Koss \& Oros, 1982). The SES is a 14-item measure of different dimensions of sexual assault and rape ranging from unwanted touching to rape with a foreign object. The questions reflect the participant's age at which the experience occurred and number of instances. T1, the SES was worded to reflect all incidents of sexual assault that had occurred between the age of 14 and the summer before freshman year of college (the time at which the participant was answering the questions). At T2, the SES was worded to reflect all incidents of sexual assault that had occurred during the first semester of freshman year, and at T3, the SES was worded to reflect all incidents of sexual assault that had occurred during the second semester of freshman year. The SES is consistent with verbal reports of victimization at $r=.73$ (Koss \& Gidycz, 1985); in this sample, internal consistency was strong with $\alpha=.81$. A revised version of the SES was published in 2007 (Koss, Abbey, Campbell, Cook, Norris, et al., 2007), but we used the original version because, to date, it rests on a more extensive body of validity evidence. The wording was adjusted on some items to reduce the level of responsibility placed on the potential victims; for example, the phrase "sex play" was removed in favor of strict behavioral descriptions (“fondling, touching, petting”) and questions referring to intoxication were edited to reflect the possibility that the respondent was intoxicated prior to initially encountering an assailant (rather than mandating that the assailant provided alcohol/drugs to the respondent in order to qualify as assault).

Sexual assault was defined as an affirmative answer to any question on the SES; when dichotomizing the sexual assault variable, a 1 was assigned to any instance of unwanted touching, coerced/forced attempted intercourse and coerced/forced intercourse and a 0 was 
assigned to those who reported no instances of any behavior assessed on the SES. This analytical approach allowed exploration of the primary question of whether exposure to sexual assault was associated with a change in subsequent grade point average. With an interest in exploring the impact of severity of the sexual assault exposure, we also created a variable contrasting two groups: those who described having been raped (they received a score of 1) and those who reported no sexual assault of any kind (they received a score of 0). Dichotomizing responses to the measure of sexual assault and rape exposure avoided the problem of zero inflation (more than half of the respondents reported no unwanted incidents) and positive skew. All participants received information about various ways to receive help from community or university clinics; those who disclosed a history of sexual assault received additional reminders about community resources.

\section{Data analysis.}

To assess the impact of sexual assault on academic performance at various points in time, we first ran a one-way analysis of variance (ANOVA) on our study variables of interest. For example, to determine the impact of a sexual assault reported at T1 on high school GPA (T1), first semester college GPA (T2), and second semester college GPA (T3), we entered all measures of GPA as dependent variables and analyzed them by the factor of the dichotomized sexual assault variable. We used the same technique to measure the impact of sexual assault during the first semester of college on GPA at T2 and T3 and to measure the specific impact of rape at T1 or T2 on GPA at T1, T2, and T3. Because T3 was the last data collection point, we could not measure the prospective impact of T3 rape or sexual assault on future GPA. We then used frequency distribution data to explore the nature of the ANOVA effects in order to better understand the clinical impact of sexual assault and rape on GPA. 
Results

\section{Descriptive Statistics}

Participants reported high school GPA at T1, first semester college GPA at T2, and second semester college GPA at T3. At T1, 73.5\% of participants reported a high school GPA of 3.5 or greater, $26.1 \%$ of participants reported a high school GPA between 2.5 and $3.4,0.3 \%$ of participants reported a high school GPA between 2.0 and 2.4, and $0.1 \%$ of participants reported a high school GPA below 2.0. This is consistent with the total population of full-time female freshmen entering the university, as the mean high school GPA for that larger group is 3.69. At T2, 46.2\% of participants reported a first semester college GPA of at least 3.5, $47.0 \%$ of participants reported a first semester college GPA of 2.5 to 3.4, 4.9\% of participants reported a first semester college GPA of 2.0 to 2.4 , and $1.9 \%$ of participants reported a first semester college GPA of less than 2.0. For all female freshmen, the mean first fall semester GPA is 3.05. At T3, 46.8\% of participants reported a second semester college GPA of 3.5 or higher, $44.8 \%$ of participants reported a second semester college GPA of 2.5 to 3.4, 6.0\% of participants reported a second semester college GPA of 2.0 to 2.4 , and $2.4 \%$ of participants reported a second semester college GPA of less than 2.0.

Sexual assault history was reported at each time point: at T1, 41.1\% of women reported some form of sexual assault having occurred since age 14, and of those women, $11.1 \%$ reported that the form of sexual assault was forced intercourse, or rape. At T2, 24.2\% of women reported some form of sexual assault having occurred during the first semester of college, and of those women, 4.1\% reported experiencing rape. At T3, 19.6\% of women reported having experienced 
some form of sexual assault during the second semester of college, and of those women, 3.1\% reported experiencing rape.

Impact of Sexual Assault and Rape on GPA: Analysis of Variance

We used a 2 (between subjects: presence or absence of sexual assault) X 3 (repeated measures: GPA measured at each wave) analytical model. T1 sexual assault (whether or not sexual assault had occurred since age 14) significantly predicted lower GPA at T1, or the end of high school $(\mathrm{F}=3.20, p<.05)$. T1 sexual assault also predicted lower GPA at T2, or the end of first semester of college $(\mathrm{F}=11.55, p<.01)$. $\mathrm{T} 1$ sexual assault also significantly predicted lower GPA at the end of the second semester of college (T3; F=3.54, $p<.05$ ). T2 sexual assault (whether or not sexual assault had occurred during the first semester of college) was significantly associated with lower GPA at T2, or the end of the first semester of college $(\mathrm{F}=5.54, p<.01)$. However, it was not significantly associated with lower GPA at T3.

We used the same design to determine the impact of rape alone on GPA. T1 rape (whether rape had occurred versus no sexual assault since age 14) significantly predicted lower GPA at T1, or the end of high school $(\mathrm{F}=4.70, p<.05)$. T1 rape also predicted lower GPA at T2, or the end of first semester of college $(\mathrm{F}=8.80, p<.01)$. T1 rape also significantly predicted lower GPA at the end of the second semester of college (T3; F=4.01, $p<.05$ ). T2 rape (whether or not rape had occurred during the first semester of college) was significantly associated with lower GPA at T2, or the end of the first semester of college $(\mathrm{F}=3.16, p<.05)$. It was also associated with lower GPA at T3 (F=3.73, $p<.05)$.

It is also important to note that neither sexual assault nor rape at T2 (the end of first semester of college) were significantly associated with GPA at T1 (high school GPA); nor was 
sexual assault or rape at T3 significantly associated with GPA at T1 or T2. Thus, GPA prior to assault was not a predictor of being an assault victim.

\section{Exploration of Significant ANOVA Effects}

To better understand the clinical impact of the significant results described above, we explored the frequency data of the GPA for those who did and did not report sexual assault and for those who did and did not report rape only. At T1, 100\% of those who did not report sexual assault from the age of 14 on had an ending high school GPA of higher than 2.5. These numbers were similar to those of participants who reported a sexual assault having occurred between the ages of 14 and the summer before college (0.8\% reported high school GPA below 2.5). The absence of a difference in high school GPA is not surprising, because high school GPA is a heavily weighted determinant of admission to the university.

Differences are more evident when looking at the college GPA of those who reported sexual assault before coming to college. Only 3.0\% of participants without a sexual assault history reported a GPA below 2.5 at the end of the first semester of college, while $10.6 \%$ of participants with a sexual assault history reported a GPA that low. At the end of the second semester of college, $5.6 \%$ of participants with no sexual assault history before college reported that their GPA was below 2.5, while $10.8 \%$ of participants with a history of assault reported the same.

We then explored the GPA of those who did and did not report having experienced a sexual assault during the first semester of college. At the end of the first semester, $4.7 \%$ of those who did not report sexual assault had a GPA below 2.5, while 7.4\% of those with a reported sexual assault had the same. At the end of the second semester, 5.9\% of those without a sexual assault reported a GPA below 2.5 while $8.9 \%$ of those with a sexual assault reported the same. 
We then explored the impact of rape alone on GPA; 1.5\% of those who reported a rape in high school also reported a high school GPA of below 2.5 (compared to $0 \%$ of those without a report of rape). At the end of the first semester of college, $8.2 \%$ of those who reported a rape in high school reported a current GPA of below 2.5 (compared to 3.0\% of those without a rape report). At the end of the second semester of college, $14.9 \%$ of those who reported a rape in high school reported a current GPA of below 2.5 (as compared to 5.6\% of those without a report of rape). We then explored the impact of rape during the first semester of college on subsequent GPA; $14.3 \%$ of those who had experienced a rape during the first semester had a GPA below 2.5 at the end of the second semester (compared to 5.9\% of those who were not raped).

\section{Discussion}

For decades, research has informed the field regarding the prevalence of rape and sexual assault against college women, its physical and psychological impacts, risk factors, reporting patterns, and legal interventions. The influence of rape and sexual assault on the academic performance of victimized women, however, has not received adequate attention in the literature. On a parallel track, academicians have explored factors that increase or decrease the likelihood that a student will matriculate through college, but these retention and persistence studies have not historically specifically considered sexual assault as a possible risk factor for dropping out. The primary purpose of this study was to address these gaps by exploring the association of rape and sexual assault with academic performance among college women. The study specifically compared high school and college sexual assault experiences with respect to collegiate GPA at key points in time; and investigated differences in GPA by type of sexual assault.

The results of the study are direct and compelling. First, mirroring numerous studies, the rate of prior sexual assault among women entering the university was exceptionally high, 
reaching more than 40 percent. An additional 24 percent experienced sexual victimization in their first semester of college, and another almost 20 percent were raped or sexually assaulted during their second semester. Secondly, there was significant evidence that the presence of rape or sexual assault in the lives of a woman, before and during college, had an identifiable impact on her academic success. The differences between women with and without sexual victimization exposure are seen immediately: women with prior sexual victimization experiences tended to enter college with lower GPA scores and tended to earn lower grades during their first freshman year than did non-victimized women. The same pattern was true for women who were sexually assaulted during their first semester; their GPA scores subsequently dropped. In short, the study made clear that a woman entering college with an average GPA who is raped or sexually assaulted in her teen years or during her first semester is more likely than a woman without that trauma to have a lower GPA by the end of her freshman year. When the form of prior victimization was rape, the association between victimization and lower GPAs was even more significant.

Notably, the experience of rape or sexual assault in the first semester was not associated with GPA upon entry to college, suggesting that GPA did not predict being a victim. Further, the experience of sexual assault in the first semester predicted lower GPA at the end of the first semester, but not the end of the second semester; it's difficult to tell whether these women's lives might have stabilized and their academic careers survived, or whether the women whose grades continued to decrease dropped out and were not among the final study participants. Strikingly, women who were raped during the first semester of college had lower GPA's both at the end of that semester and at the end of the following semester. In total, the findings of the study make clear that women who are sexually assaulted or raped in their teen years enter college with a 
distinct disadvantage (as measured by GPA) with respect to their ability to achieve academic success; and that their physical safety while a student in college is directly related to their grades.

The study also provided important detail regarding the specific level of harm done to the GPAs of victims. Women with sexual victimization history before college were over three times more likely than non-victims to have a GPA below 2.5 at the end of their first semester; and almost twice as likely to have that low GPA at the end of their second semesters. When the prior experience of sexual assault was rape, the rate of women with GPAs below 2.5 was even higher. The same pattern is seen among women who experience rape or sexual assault in their first semesters; significantly higher percentages of those women have GPAs below 2.5. The most dramatic impact is seen for women who experience a forcible rape in their first semester of college; fully 14.3 percent of those women end the semester with a GPA below 2.5. This latter point communicates that the level of negative academic impact is positively related to the severity of a woman’s victimization.

There are findings within the extant victimization and retention literatures that resonate with the findings of this current study. While the sexual assault literature has not focused on grades per se, it follows that a woman suffering sequelae in the aftermath of a rape may experience cognitive impairment such that she is less able to concentrate, organize a set of facts, or remember details in the course of her studies. Depression or anxiety may diminish the energy a woman has to commit to academic work or decrease her ability to engage with other students due to social anxiety, shame, or embarrassment. There is also evidence that victimized women may turn to substance abuse as a coping mechanism which could negatively affect grades. In addition to mental health and substance abuse, there may be other changes to a woman's social or family environment that function as the mechanism creating a link between victimization and 
poor academic performance. Any of these individual or environmental factors could relate to worsening performance in the classroom, but the specific mechanisms by which grades drop following rape and sexual assault needs further exploration.

The retention literature has theorized that individual student characteristics and student engagement (often defined to mean communication and activities with other students and institutional activities) are important influences on student retention. This study would suggest that a history of rape or sexual assault and the ways in which a woman’s surroundings and experiences change following an assault are likely to be very important. However, what bearing a rape or sexual assault has on a woman's ability to manage the typical stressors of freshman year or spend time with other students is not adequately understood. This study makes clear that this lack of understanding is a critical omission in the literature, particularly in light of the fact that first-year students are the group at greatest risk of attrition from universities.

This study is an important first step in establishing a link between a woman's exposure to rape or sexual assault and her subsequent academic performance. It is limited by the fact that it was a web-based survey study dependent upon the self-disclosure of victimization. Additionally, the measure of GPA was not specific, relying on students’ self-report by category, not on a registrar record. This is of concern as research suggests that self-reported grades are less construct valid than previously believed (e.g., Kuncel, Credé, \& Thomas, 2005). Additionally, the negative impact of sexual assault on a woman's academic career could well be underestimated by this study given that some of the women who did not complete the regimen of surveys could have dropped out of the university. It was outside the scope of the study to measure attrition due to victimization. Future research should build upon the findings in this study, first by analyzing in greater detail the type of sexual victimization experienced and level 
of impact on academic performance (extending beyond the dichotomous variable approach used here); and by expanding types of victimization to include physical assault by an intimate and stalking.

The findings of this study should send strong messages to universities across the nation. First, the study augments the substantial extant evidence that sexual assault has a deleterious impact on college women by adding academic impairment to negative health and mental health sequelae and substance abuse already documented to follow its occurrence. To attend to the wellbeing of students and to make every effort to ensure equal access to and benefit from education, institutions of higher learning must commit in stronger measure to preventing sexual assault on its campuses and in its environs. Additionally, researchers studying both retention/persistence patterns and sexual assault incidence among college students should ensure that the relationship between the two is included in research designs. Finally, the study makes clear that professionals on campuses with expertise in victimization (through student affairs, women's programs, or counseling programs) should work closely with staff in admissions, academic advising, and retention programs to address the safety of college women. Findings such as those in this study mean it is no longer acceptable in the structure of university departments to separate academic initiatives and policy from the physical and psychological safety of students. 


\section{Author Notes}

Portions of this research were supported by NIAAA grant F31 AA020767-01 and by a Cralle-Day Young Scholars grant from the University of Kentucky Center for Research on Violence Against Women, both to Jessica L. Combs. 


\section{References}

Abbey, A., Ross, L.T., McDuffie, D. \& McAuslan, P. (1996). Alcohol and dating risk factors for sexual assault among college women. Psychology of Women Quarterly 20,147-169.

Abbey A., McAuslan, P., \& Ross, L.T. (1998). Sexual assault perpetration by college men: The role of alcohol, misperception of sexual intent, and sexual beliefs and experiences. Journal of Social and Clinical Psychology, 17, 167-195.

Abbey, A., McAuslan, P., Zwacki, T., Clinton, A. M. \& Buck, P. O. (2001). Attitudinal, experimental, and situational predictors of sexual assault perpetration. Journal of Interpersonal Violence, 16, 784-807.

Abbey, A. (2002). Alcohol-related sexual assault: A common problem among college students. Journal of Studies on Alcohol, 14, 118 - 128.

Abbey, A. (2002). Alcohol-related sexual assault: A common problem among college students. Journal of Studies on Alcohol, 63(2), 118-129.

Abbey, A., Parkhill, M.R., BeShears, R., Clinton-Sherrod, A.M., \& Zawacki, T. (2006). Crosssectional predictors of sexual assault perpetration in a community sample of single African American and Caucasian men. Aggressive Behavior, 32, 54-67.

Ackard, D. M., \& Neumark-Sztainer, D. (2002). Date violence and date rape among adolescents: Associations with disordered eating behaviors and psychological health. Child Abuse and Neglect, 26, 455-473.

Amar, A.F., \& Gennaro, S. (2005). Dating violence in college women: Associated physical injury, health care usage, and mental health symptoms. Nursing Research, 54(4), 235242. 
Belknap, J. \& Erez, E. (1995). The Victimization of women on college campuses: Courtship violence, date rape, and sexual harassment, (156-178). In Campus Crime: Legal, Social, and Policy Perspectives ( B. S. Fisher and I. Sloan, John J., Eds.). Springfield, Illinois: Charles C. Thomas Publisher.

Berkner, L., He, S., Cataldi, E.F., \& Knepper, P. (2002).Descriptive summary of 1995-96 beginning postsecondary students: Six years later. Washington, DC: National Center for Education Statistics.

Braxton, J. M., Hirschy, A. S., \& McClendon, S. A. (2004). Understanding and reducing college student departure. Higher Education Report, 30(3). San Francisco: Jossey-Bass.

Braxton, J.M. (2000). Introduction: Reworking the student departure puzzle. In J. Braxton (Ed.), Reworking the Student Departure Puzzle (pp. 1-8). Nashville, TN: Vanderbilt University Press.

Briere, J., \& Jordan, C.E. (2004). Violence against women: Outcome complexity and implications for treatment. Journal of Interpersonal Violence, 19, 1252-1276.

Campbell R, Dworkin E, Cabral G. (2009). An ecological model of the impact of sexual assault on women’s mental health. Trauma Violence Abuse 10(3): 225-46

Carey, K. (2004, May). A matter of degrees: Improving graduation rates in four-year colleges and universities. Washington, DC: Education Trust.

Copenhaver, S., \& Grauerholz, E. (1991). Sexual victimization among sorority women: Exploring the links between sexual violence and institutional practices. Sex Roles, 24(12), 31-41. 
Combs, J.L., Jordan, C.E., \& Smith, G.T. (in press). Individual differences in personality predict externalizing versus Internalizing outcomes following sexual assault. Psychological Trauma: Theory, Research, Practice, and Policy,

Danielson, C. K., \& Holmes, M. M. (2004). Adolescent sexual assault: an update of the literature. Current Opinion Obstetrics and Gynecology, 16, 383-388.

Duncan, R.D. (2000). Maltreatment and college drop-out rates: Implications for child abuse researchers. Journal of Interpersonal Violence, 15, 987 - 995.

Faravelli, C., Guigni, A., Salvatori, S., \& Ricci, V. (2004). Psychopathology after rape. American Journal of Psychiatry, 161, 1483-1485.

Finkelhor, D., Turner, H., Ormrod, R., \& Hamby, S. L. (2009). Violence, abuse, and crime exposure in a national sample of children and youth. Pediatrics, 124, 1411-1423.

Fisher, B.S., \& Sloan, J. J. (2007). Campus crime: Legal, social, and policy perspectives. Springfield, Illinois: Charles C. Thomas Publisher, Ltd.

Fisher, B.S., Cullen, F.T., Turner, M.G. (2000). The sexual victimization of college women. (182369). Washington DC: U.S. Department of Justice, Office of Justice Programs.

Fries-Britt, S., \& Turner, B. (2002). Uneven stories: Successful Black collegians at a black and white campus. The Review of Higher Education. 25(3), 315 - 330.

Grayson, J.P., \& Grayson, K. (2003). Research on retention and attrition. Retrieved May 23, 2013, http://www.millenniumscholarships.ca/images/Publications/retention_final.pdf

Gupton, J.T., Castelo-Rodriguez, C., Martinez, D.A., \& Quintanar, I. (2009). Creating a pipeline to engage low-income, first-generation college students. In S. Harper, \& J. Quaye (Eds.), Student engagement in higher education: Theoretical perspectives and practical approaches for diverse populations (pp. 243-260). New York, NY: Routledge. 
Hammig B, Jozkowski K. (2013). Academic achievement, violent victimization, and bullying among U.S. high school students. Journal of Interpersonal Violence, 28(7), 1424-1436.

Harper, S.R., \& Quaye, S.J. (2009). Beyond sameness, with engagement and outcomes for all: An introduction. In S. Harper, \& J. Quaye (Eds.), Student engagement in higher education: Theoretical perspectives and practical approaches for diverse populations (pp. 1-15). New York, NY: Routledge.

Harrington, N.T., \& Leitenberg, H. (1994). Relationship between alcohol consumption and victim behaviors immediately preceding sexual aggression by an acquaintance. Violence and Victims, 9: 315-324.

Herman J.L. 1992. Complex PTSD: A syndrome in survivors of prolonged and repeated trauma. Journal of Traumatic Stress, 5(3):377-91.

Huerta, M., Cortina, L.M., Pang, J.S., Torges, C.M., \& Magley, V.J. (2006). Sex and power in the academy: Modeling sexual harassment in the lives of college women. Personality and Social Psychology Bulletin, 32, 616-628.

Humphrey, J.A., \& White, J.W. (2000). Women’s vulnerability to sexual assault from adolescence to young adulthood. Journal of Adolescent Health, 27,419-424.

Jordan, C.E., Campbell, R., \& Follingstad, D. (2010). Violence and women’s mental health: The impact of physical, sexual, and psychological aggression. Annual Review of Clinical Psychology, 6, 607-628.

Kaura, S.A., \& Lohman, B.J. (2007). Dating violence victimization, relationship satisfaction, mental health problems, and acceptability of violence: A comparison of men and women. Journal of Family Violence, 22, 367 - 381. 
Kilpatrick, D.G., Saunders, B.E., \& Smith, D.W. (2003). Youth victimization: Prevalence and implications. (Findings from the National Survey of Adolescents). Washington, DC: National Institute of Justice, U.S. Department of Justice.

Koss, M. P., \& Oros, C. J. (1982). The Sexual Experience Survey: An empirical instrument investigating sexual aggression and victimization. Journal of Consulting and Clinical Psychology, 50, 455-457.

Koss, M. P., \& Gidycz, C. A. (1985). The sexual experiences survey: Reliability and validity. Journal of Consulting and Clinical Psychology, 53, 442-423.

Koss, M.P., Gidycz, C.A. \& Wisniewski, N. (1987). The scope of rape: Incidence and prevalence of sexual aggression and victimization in a national sample of higher Eleducation students. Journal of Consulting and Clinical Psychology 55, 162-170.

Koss, M.P., Goodman, L.A., Browne, A., Fitzgerald, L.F. Keita, G.P., \& Russo, N.F. (1994). No safe haven: Male violence against women at home, at work, ad in the community. Washington DC: American Psychological Association.

Koss, M.P., Abbey, A., Campbell, R., Cook, S., Norris, J., Testa, M., Ullman, S., West, C., \& White, J. (2007). Revising the SES: A collaborative process to improve assessment of sexual aggression and victimization. Psychology of Women Quarterly, 31, 357-370.

Kuncel, N.R., Credé, M., \& Thomas, L.L. (2005). The validity of self-reported grade point averages, class ranks, and test scores: A meta-analysis and review of the literature. Review of Educational Research, 75(1), 63 - 82.

Maxwell, C.D., Robinson, A.L., \& Post, L.A. (2003). The nature and predictors of sexual offending among adolescents. Journal of Youth and Adolescence, 32, 465-478 
Mills, C.S., \& Granoff, B.J. (1992). Date and acquaintance rape among a sample of college students. Social Work 37, 504-509.

Mohler-Kuo, M., Dowdall, G.W., Koss, M.P., \& Wechsler, H. (2004). Correlates of rape while intoxicated in a national sample of college women. Journal of Studies on Alcohol, 65(1), $37-45$.

Muehlenhard, C. L., \& Linton, M. A. (1987). Date rape and sexual aggression in dating situations: Incidence and risk factors. Journal of Counseling Psychology, 34, 186-196.

National Center for Education Statistics (2003). Descriptive summary of 1995-96 beginning postsecondary students: Six years later. NCES, Statistical Analysis Report 2003-151. Washington DC: U.S. Department of Education, Office of Educational Research and Improvement.

National Center for Education Statistics (2009). Digest of education statistics. Washington DC: U.S. Department of Education, Office of Educational Research and Improvement.

Raj, A., Silverman, J. G., \& Amaro, H. (2000). The relationship between sexual abuse and sexual risk among high school students: Findings from the 1997 Massachusetts Youth Risk Behavior Survey. Maternal and Child Health Journal, 4(2), 125-133.

Rennison, C.M. (2001). Criminal Victimization 2000: Changes 1999-2000 with trends 19932000. National Crime Victimization Survey (NCJ 187007). Washington, D.C. Bureau of Justice Statistics, U.S. Department of Justice.

Rhea, M., Chafey, K., Dohner, V., and Terragno, R. (1996). The silent victims of domestic violence: Who will speak? Journal of Child and Adolescent Psychiatric Nursing, 9(3): 715. 
Ross, L. T., Kolars, C. L. K., Krahn, D. D., Gomberg, E. S. L., Clark, G., \& Niehaus, A. (2011). Nonconsensual sexual experiences and alcohol consumption among women entering college. Journal of Interpersonal Violence, 26(3), 399-413.

Rozee, P.D., Koss, M.P. (2001). Rape: A century of resistance. Psychology of Women Quarterly, 25(4), $295-311$.

Schoen, C., Davis, K., Collins, K. S., Greenberg, L., Des Roches, C., \& Abrams, M. (1997). The Commonwealth Fund survey of the health of adolescent girls. Retrieved from http://www.commonwealthfund.org/Content/Publications/Fund-Reports/1997/Nov/TheCommonwealth-Fund-Survey-of-the-Health-of-Adolescent-Girls.aspx.

Schwartz, M. D., DeKeseredy, W. S., Tait, D., \& Alvi, S. (2001). Male peer support and a feminist routine activities theory: Understanding sexual assault on the college campus. Justice Quarterly, 18, 623-649.

Silverman, J. G., Raj, A., Mucci, L. A., \& Hathaway, J. E. (2001). Dating violence against adolescent girls and associated substance use, unhealthy weight control, sexual risk behavior, pregnancy, and suicidality. Journal of the American Medical Association, 286(5), 572-579.

Smith, P.H., White, J.W., \& Holland, L.J. (2003). A longitudinal perspective on dating violence among adolescent and college-age women. American Journal of Public Health, 93, 11041109.

Thombs, D.L., Olds, R.S., Body, S.J., Winchell, J., Baliunas, D., \& Rehm, J. (2009). Undergraduate ddrinking and academic performace: A perspective innvestigation with objective measures. Journal of the Study of Alcohol and Drugs, 70(5), 776 - 785. 
Tinto, V. (2007). Research and practice of student retention: What next? Journal of College Student Retention: Research, Theory \& Practice 8, 1 - 19.

Tinto, V. (2004). Student Retention and graduation: Facing the truth, living with the consequences. Washington, DC: The Pell Institute.

Tinto, V. (1993). Leaving college: Rethinking the causes and cures of student attrition (2 $2^{\text {nd }}$ Edition). Chicago, Illinois: The University of Chicago Press.

Tinto, V (1975) Dropout from higher education: A theoretical synthesis of recent research. Review of Educational Research, 45(1), 89 - 125.

Tjaden, P. \& Thoennes, N. (1998). Prevalence, incidence, and consequences of violence against women: Findings from the National Violence Against Women Survey (NCJ 172837). Washington, DC: National Institute of Justice, U.S. Department of Justice.

Tjaden, P. \& Thoennes, N. (2006). Extent, nature, and consequences of rape victimization: Findings from the National Violence Against Women Survey. Washington, DC: National Institute of Justice, U.S. Department of Justice.

van Roosmalen, E., \& McDaniel, S.A. (1998). Sexual harassment in academia: A hazard to women's health. Women Health, 28(2):33-54

White, J.W., \& Koss, M.P. (1991). Courtship violence: incidene and prevalence in a national sample of higher education students. Violence and Victims, 6, 247 - 256.

Wilcox, P., Jordan, C.E., \& Pritchard, A.J. (2006). Fear of acquaintance versus stranger rape as a master status: Towards refinement of the shadow of sexual assault. Violence and Victims, 21 (3), $355-370$. 
Young, A.M., Grey, M., \& Boyd, C.J. (2009). Adolescents’ experiences of sexual assault by peers: prevalence and nature of victimization occurring within and outside of school. Journal of Youth and Adolescence, 38, 1072-83. 


\section{MAJOR FINDINGS}

- More than $40 \%$ of the women entering the study university had an experience of rape or sexual assault during their teen years; an additional $24 \%$ experienced sexual victimization in their first semester of college, and another almost $20 \%$ were raped or sexually assaulted during their second semester of college.

- Women with prior teen sexual victimization experiences tended to enter college with lower GPA scores and tended to earn lower grades during their first freshman year than did non-victimized women students.

- Women sexually assaulted during their first semester of college tended to have lower GPAs by the end of the semester than did women without a sexual assault experience during the first semester.

- The level of negative academic impact on a woman's academic performance was positively related to the severity of her victimization: higher rates of GPAs under-2.5 were seen among women those whose assault experience was a rape as compared to other forms of sexual assault.

\section{IMPLICATIONS FOR PRACTICE, POLICY AND RESEARCH}

- Study findings emphasize that clinicians, counselors, and advocates working with college women who are victims of rape and sexual assault need to attend to academic performance and ensure that if class attendance, examinations, or grades are a challenge, that adequate advising and other supports are available.

- Student affairs, admissions, and academic advising professionals on college campuses need to include the risk of victimization among factors included in retention programming.

- Researchers studying retention/persistence patterns in higher education settings, and those studying sexual assault among college students need to ensure that the relationship between victimization and academic performance is included in research designs. 


\section{FUTURE READING}

Abbey, A. (2002). Alcohol-related sexual assault: A common problem among college students. Journal of Studies on Alcohol, 63(2), 118-129.

Campbell R, Dworkin E, Cabral G. (2009). An ecological model of the impact of sexual assault on women's mental health. Trauma Violence Abuse 10(3): 225-46

Fisher, B.S., Cullen, F.T., Turner, M.G. (2000). The sexual victimization of college women. (182369). Washington DC: U.S. Department of Justice, Office of Justice Programs.

Tinto, V. (2007). Research and practice of student retention: What next? Journal of College Student Retention: Research, Theory \& Practice 8, 1 - 19. 


\section{Author Biographies}

Carol E. Jordan serves as Executive Director of the University

Kentucky Institute on Violence Against Women Policy Studies and holds faculty appointments in the Departments of Psychology and Psychiatry at the University. Jordan has authored three books, eight book chapters and approximately 35 peer reviewed articles on violence against women, particularly focusing on civil and criminal justice issues; the victimization of college women; and the legislative history of addressing violence

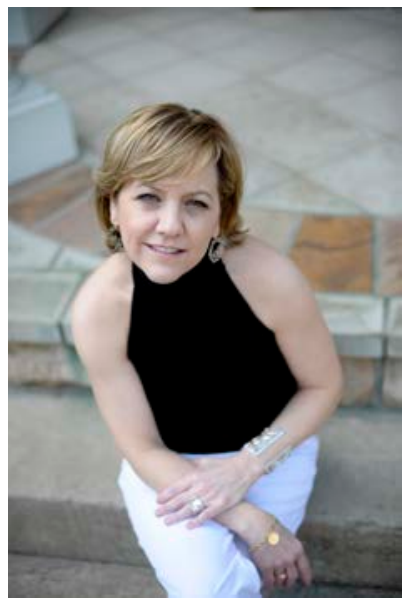
against women. Jordan has managed grants totaling more than $\$ 3.5$ million and since coming to UK has built a \$6.2 million research and education endowment. Jordan has over 30 years of experience in research, public policy, legislative advocacy, and the development of programs addressing intimate partner violence, rape, and stalking. Before coming to the University, Jordan served as Executive Director of the Office of Child Abuse and Domestic Violence Services in the Office of the Kentucky Governor.

Jessica Combs is completing her doctoral degree in clinical psychology at the University of Kentucky in Lexington, KY under the mentorship of Gregory T. Smith, Ph.D. She graduated summa cum laude from Emory University in Atlanta, GA with a bachelor's degree in psychology. Her research background is primarily in the study of personality factors in the prediction of externalizing

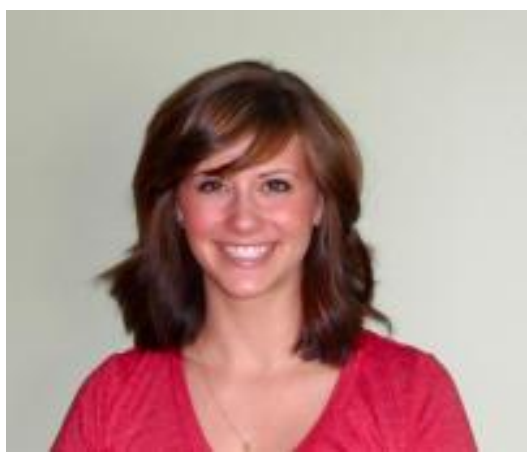
behaviors, and she recently has begun to develop a research line exploring the impact of sexual 
trauma on person-behavior relationships. She is currently a pre-doctoral intern at the Michael E. DeBakey Veterans Affairs Medical Center in Houston, TX where she continues to research different types of trauma and the long-lasting and widespread impact each can have on an individual's functioning

Gregory T. Smith is a Professor, University Research Professor, and Director of the doctoral program in clinical psychology at the University of Kentucky, where he has served on the faculty since 1989. He has conducted research in risk for addictive behavior involvement, including alcohol abuse and eating disorders, for over 20 years. His work has been funded by the National Institute on Alcohol Abuse and Alcoholism, and by the National Institute on Drug Abuse. More

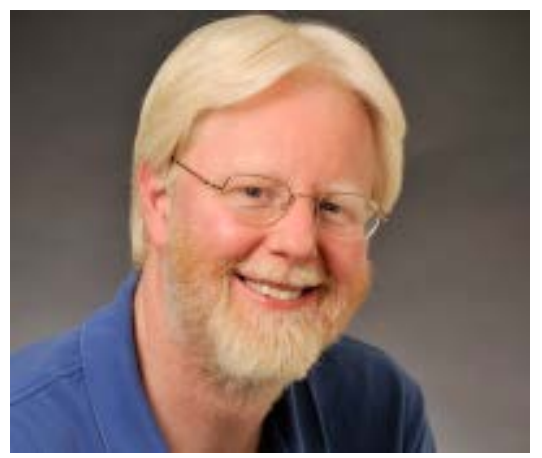
recently, his laboratory has begun to investigate sequelae of sexual trauma, including the impact of trauma on subsequent problem drinking. He has published over 140 empirical articles and book chapters, and a book on the methods of psychological assessment. He has served two terms as an Associate Editor of the Journal of Abnormal Psychology and one term as an Associate Editor of Psychological Assessment. 